\title{
Comparison of Work Motivation and Working Conditions on The Performance of Msmes Employees Before and During Covid-19
}

\author{
Agus Dwi Cahya', Bagus Disfantoro², Khusniah ${ }^{3}$
}

\author{
1-3 Universitas Sarjanawiyata Tamansiswa, email : agusdc@ustjogjagmail.ac.id, \\ bagusdisfanto@gmail.com, khusnia469@gmail.com
}

\begin{tabular}{|c|c|}
\hline $\begin{array}{l}\text { ARTICLES } \\
\text { INFORMATION }\end{array}$ & ABSTRACT \\
\hline
\end{tabular}

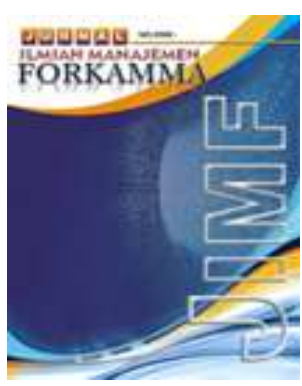

\section{JURNAL ILMIAH MANAJEMEN FORKAMMA}

Vol.4, No.3, Juli 2021

Halaman : $262-277$

(C) LPPM \& FORKAMMA

Prodi Magister Manajemen UNVERSITAS PAMULANG

ISSN (online) : 2599-171X

ISSN (print) : :2598-9545

Keyword:

Work Motivation, Work

Conditions, Employee

Performance

JEL. classification :

O15,

Contact Author :

PRODI
MAGISTER MANAJEMEN \&
FORKAMMA UNPAM
JL.Surya Kencana No.1 Pamulang
Tangerang Selatan - Banten
Telp. (021) 7412566, Fax (021) 7412491
Email :
jurnalforkamma.unpam@gmail.com

\begin{abstract}
The purpose of this study was to compare the effect of work motivation and working conditions on the performance of MSME employees before and during the Covid-19 pandemic. The researcher uses a comparative research type with a quantitative approach. Techniques Data collection is done using a questionnaire with the linkert method. And the sampling technique used is to use a saturated sample (total sampling). The total sample obtained is 37 employees from several MSMEs. In the test of the effect of work motivation, work motivation has no significant effect on employee performance. Variable working conditions have a significant effect on employee performance. In the $F$ test there is an influence between work motivation and working conditions on employee performance. And in the comparison test, there is a significant difference between work motivation and working conditions before and during covid-19. While in the employee performance variable there is no significant difference between employee performance before and during Covid-19.
\end{abstract}

Keywords: Employee Performance; Work Condition; Work Motivation 


\section{A. INTRODUCTION}

The emergence of Covid-19 began in early 2019. Covid-19 is becoming an outbreak for the whole world not only China. This has an impact on the global economic slowdown in the country.

From the data that processed by P2E LIPI, the impact of Covid-19 provides a decrease in MSMEs engaged in various business sectors, among others: a decrease of $27 \%$ occurs in the micro food and beverage business sector. $1.77 \%$ impact on small food and beverage businesses, and $0.27 \%$ on medium enterprises. While $1.77 \%$ for small businesses and $0.01 \%$ for medium enterprises in the middle business sector. Overall the influence of the covid-19 virus will be at $17.03 \%$ of the units of wood handicrafts and rattan micro businesses. While between $0.5 \%$ to $0.8 \%$ affects the household consumption sector. Data from the Ministry of Cooperatives and Small and Medium Enterprises of Indonesia in 2018 showed that 62.9 million MSMEs units, 97\% absorbed the workforce from the total keseluhan. $89 \%$ of them are in the micro sector, as well as $60 \%$ of gross domistic product. (Bahtiar \&Saragih, 2020)

The Government of Indonesia implements policies to suppress the spread of Covid19 in ways such as: physical distancing, social distancing for individuals, then the Enforcement of Restrictions on Community Activities (PPKM) and Large-Scale Social Restrictions (PSBB) for the entire community. Changes in lifestyle and habits are also felt for all levels of society with the implementation of the policy. The same is felt in the company's world activities, entrepreneurship, so that it also has an impact on the system of workforce reduction through employee layoffs, the cessation of trade and business activities, even the economy is almost dead as everyone feels.

Daily activities both indoor or outdoor sech as campus activities should be familiar with new normal condition, nad the new normal is not esay to be implemented and need adaptation on it.

Motivation is an element that arouses one's desire in carrying out activities. Motivation can also be interpreted as a stimulus that comes either from within a person or from outside oneself in doing something, the motivation that arises will make a person more excited, flowing, and enterprising in achieving his goals. Just like the conditions of work that raises can also provide encouragement in work.

According to Setywan (2020) Motivation desire that evokes the spirit of one's work to work well and work professionally with efforts in obtaining the center.

Hartanto et al. (2018) explained that working conditions are physical, social and environmental factors that affect the work environment for workers. Working conditions can also be interpreted as the state of employees in the workplace in carrying out their work both physically, psychologically and in place and social relations in the workplace.

Employee performance can be interpreted as employee work achievements that are assessed from the quality and quantity of people in work based on work standards that have been determined by the organization. Good performance is performance that aligns with organizational standards and supports the achievement of organizational goals. (Isvandiari \&Fuadah, 2017).

Based on the above descriptions, the problem formulation in this study is as follows: Does work motivation have a significant impact on the performance of MSMEs employees before and during Covid-19? Does working conditions have a significant impact on the performance of MSME employees before and during Covid-19? Does simultaneous work motivation and working conditions have a significant impact on the performance of MSME employees before and during Covid-19? Is there a significant difference between work motivation in the period before and during covid-19? Is there a significant difference between working conditions in the period before and during Covid-19? Is there a significant difference in employee performance before and during Covid-19? 
The objectives of this research are as follows.:To find out the effect of work motivation on the performance of MSME employees before and during Covid-19. To find out the effect of working conditions on the performance of MSME employees before and during Covid-19. To know the effect of work motivation and working conditions simultaneously on the performance of MSME employees before and during Covid-19. To find out if there is a significant difference between work motivation in the period before and during covid-19. To find out if there are significant differences between working conditions in the period before and during Covid-19. To find out if there are significant differences in employee performance before and during Covid-19?

\section{B. LITERATURE STUDIES}

\section{Pandemic Covid-19}

The term epidemic and pandemic was familiar when the Covid-19 outbreak appeared in Wuhan China. Linguistically, epidemic is an infectious disease that infects people rapidly in a wide area and causes many casualties. Meanwhile, pandemics are defined as epidemics that occur and affect people all over the world or vast areas across international borders. WHO designates Covid-19 as a global pandemic based on the rapid and widespread spread in some countries and even the world and affects people's lives. (Agung, 2020).

According to data from the National Health Commission of China as of Tuesday, February 11, 2020, the death toll of coronavirus in mainland China has reached 1,016, and there are still a variety of new confirmed cases so that the number continues to grow. Covid-19 is an infectious disease by severe acute respiratory syndrome 2 or SARS-Cov-2. This virus is corona virus that often attacks animals. When attacking humans usually cause respiratory tract infections, such as flu, MERS (Middle East Respiratori Syndrome). The covid virus is a bari virus that originated in Wuhan, Hubei, China in 2019. (Amri, 2020)

\section{Working Condition}

Hartanto et al. (2018) explained that working conditions are physical, social and circumstances that affect the work environment for workers. Working conditions can also be interpreted as the state of employees in the workplace in carrying out their work both physically, psychologically and in place and social relations in the workplace.

Working conditions are everything in the employee's work environment that can affect him/her in carrying out tasks, such as temperature, humidity, ventilation, lighting, noise, workplace cleanliness, work equipment conditions, and unclear tasks and responsibilities (Salutondok \&Soegoto2, 2015).Motivasi Kerja

According to Surjosuseno (2015) that motivation comes from the Latin word movere which means drive or drive force. Motivation is given to people especially to workers or employees. Work motivation becomes one of the triggers for employees to produce good performance. the lack of motivation in work affects one's performance in carrying out their duties even though employees have qualified potential.

According to Bawono et al. (2019) the term, motive is the same as the words motive, motip, dorongan, alasan and driving force. The reason that encourages a person to act or a desire that causes someone to act.

According to Lawasi \&Triatmanto (2017) human needs as follows:

1. Physiological needs, including food, clothing, and housing and biological needs.

2. Security and safety needs, including the need for work security, freedom from fear, or pressure, security from events or environments that threaten 
3. The need to have a social soul and compassion (social), including the need for friendship, family, grouping, and interacting.

4. The need for esteem, including the need for self-esteem, status, dignity, honor, and appreciation from other parties.

5. The need for self actualization, which includes the need to meet self fulfillment by maximizing self-capability and potential.

According to Setywan (2020) Motivation is things that can arouse the employee's work passion, so that employees are willing to work diligently to carry out their duties. Motivation indicators there are emapat namely 1) niai work for employees; 2) satisfaction level; 3) good working relationship; 4) self-development.

\section{Employee Peformance}

According to Astarina (2018) Performance can be interpreted as the result of work achieved by a person or group such as the standard of work, targets determined over a certain period of time, operational standards of work procedures, criteria and functions that have been determined or applicable in the company.

Employee performance is the result or achievement of employee work that is assessed in terms of quantity and quality based on the terms and standards of work that has been regulated by the organization Good performance is optimal performance, namely performance in accordance with organizational standards and support the achievement of the objectives of the organization. (Isvandiari \&Fuadah, 2017).

\section{Motivational Relationships with Employee Performance}

In lawasi \&triatmanto research (2017) entitled "The Influence of Communication, Motivation and Teamwork on Employee Performance Improvement". In this study obtained motivational results positively and significantly affect the performance of karayawan in sahid montana hotel 1 Malang.

Montolalu et al. (2021) entitled "Comparative Analysis of Performance, Job Satisfaction, Work Motivation, Organizational Commitment to Permanent Employees And Non-Permanent Employees at Sintesa Peninsula Hotel Manado" the results showed significant differences in work motivation in the wealthy permanent employees and contract employees at Sintesa Peninsula Hotel Manado.

\section{Working Conditions Relationship with Employee Performance}

Hartanto et al. (2018) entitled "Analysis of the influence of working conditions, work motivation, and work discipline on the performance of employees of regional offices of the directorate general of wealth of Riau, West Sumatra, and Riau Islands" the results of this study showed that working conditions have a significant influence on the performance of employees of regional offices directorate general of wealth riau, West Sumatra, and Riau Islands.

\section{Motivational Relationships, Working Conditions, Equally To Employee Performance}

In the study of Hartanto et al. (2018) entitled "Analysis of the influence of working conditions, work motivation, and work discipline on the performance of employees of regional offices of the directorate general of wealth of Riau, West Sumatra, and Riau Islands" shows the influence of working conditions, work motivation, and work discipline together on employees of the directorate general of wealth of Riau State, West Sumatra, and Riau Islands. 


\section{Hypothesis}

Based on the description above, the hypotheses proposed in this study are as follows:

$\mathrm{H} 1$ : It is suspected that work motivation has a significant impact on the performance of MSME employees before and during Covid-19

$\mathrm{H} 2$ : It is suspected that work motivation has a significant impact on the performance of MSME employees before and during Covid-19

H3: It is suspected that work motivation and working conditions simultaneously have a significant effect on the performance of MSME employees before and during Covid-19

$\mathrm{H} 4$ : It is suspected that there is a significant difference between work motivation in the period before and during covid-19

H5: It is suspected that there is a significant difference between working conditions in the period before and during Covid-19

H6: There are suspected significant differences in employee performance before and during Covid-19

\section{Frame Work}

From the description above the framework of thinkers in this study are as follows.

Picture 1. Frame of Mind

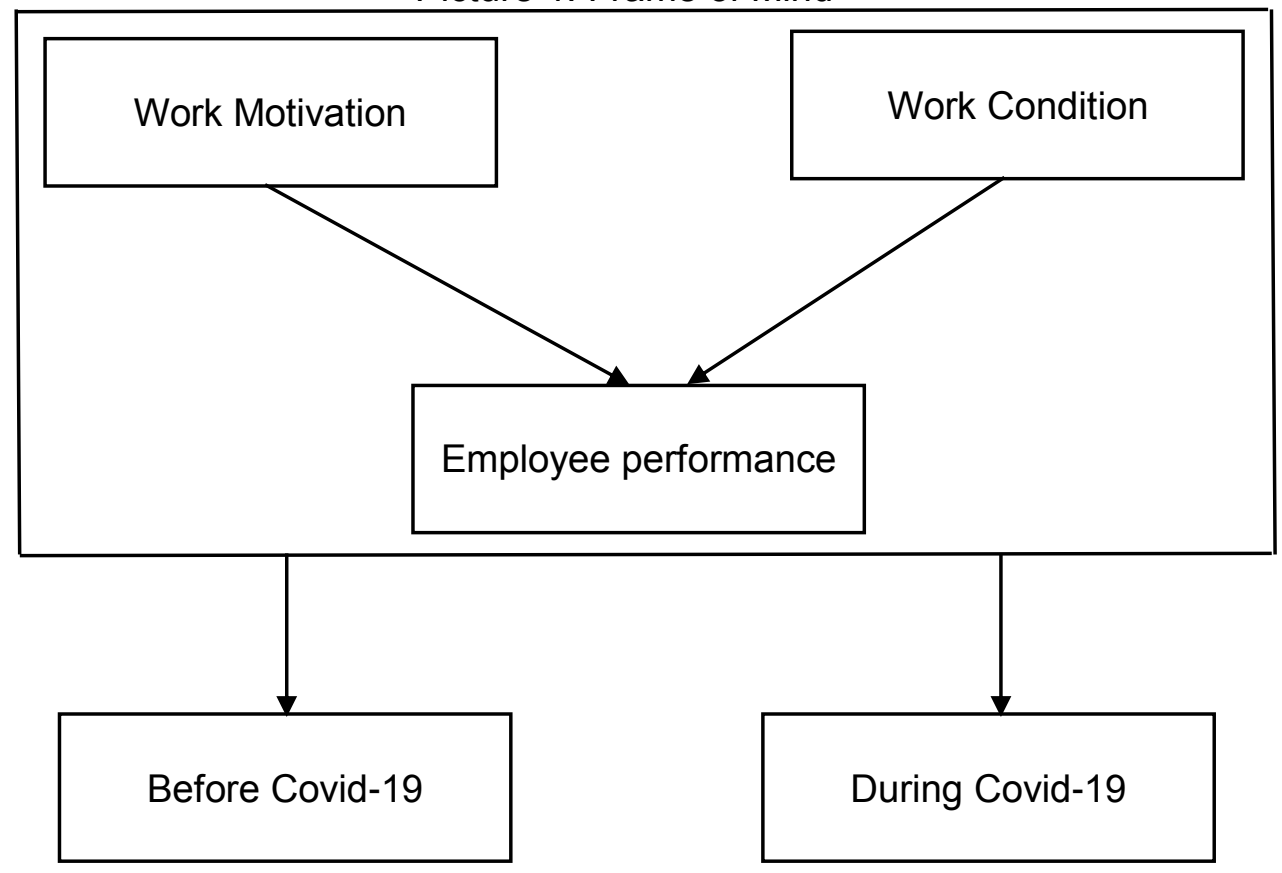

\section{RESEARCH METHODOLOGY}

\section{Types of Research}

This research was done using a type of descriptive comparative research as well as using quantitative approaches. Quantitative approach according to Nawastuti (2018) is an approach that is done by collecting data in the form of numbers which then the data is processed using certain applications to obtain information behind the numbers. The purpose of this type of comparative research according to Sugiyono (2013) is a study that compares the circumstances of one or more variables on two or more different samples, or two different times as well. In this study, the authors examined the comparison of the influence between work motivation and working conditions in the performance of MSMEs employees before and during the Covid-19 pandemic 


\section{Population and Samples}

Population, Sugiyono (2013) Explaining the population is a generalisai object / subject that has characteristics and qualities in accordance with the researcher's kententuan as an element studied then concluded as a research pegai. In this study, the population was karayawan UMKM Kopi Merapi, Gelea Kopi, Urbant Parfum Jogja, and Mym Mandiri.

Samples, According to Sugiyono (2013) the sample is part of the object/subject chosen to represent the entire population. Syafrina (2017) if the subject or research obje less than 100 , then it is better that all popolasi taken is used as a sample in the study. So this study researchers use the technique of taking through census method or saturated sample (total sampling) i.e. population is used as a sample. The number of samples that can be taken amounts to 37 employees of MSMEs that have been mentioned in the population.

\section{Data Source}

\section{Data Collection Resources and Techniques}

In this study the data source used is primary data. Maulana (2015) explained that Primary data is data directly obtained from companies or organizations, especially employees who are the object of research. This study researchers used primary data sources obtained from MSME employees through questionnaires. Data Collection Techniques

The technique used to collect data in this study is a research instrument in the form of questionnaires. The questionnaire method uses the Likert method. In Sugiyono (2015) likert scale is a scale or measuring instrument used to measure the opinions, attitudes and perceptions of a person or group of people about social phenomena.

In the scale linkert answers are divided into subjects stated in 5 categories, namely:

1. Strongly Agree (SS) calculated score of 5

2. Agree (S) score 4

3. Neutral $(\mathrm{N})$ score 3

4. Disagree (TS) score 2

5. Strongly Disagree (STS) score 1

\section{Data Analysis Methods}

The data analysis methods used in this study are as follows.

1. Validity Test

According to Sugiyono (2013) validity test is a test of accuracy between data that occurs in research objects and power that can be reported by researchers. This test describes whether or not an instrument in research is used in a study.

2. Reliability Test

Reliability is the degree of accuracy or accuracy indicated by the measurement instrument. In general, a valid instrument is certainly reliable, but a reliable instrument is not necessarily valid, therefore it is necessary to test the reliability of the instrument. (Maulana, 2015)

3. Classic Assumption Test

Maulana (2015) explains the classic assumption test consists of:

a. Normality Test

The normality test aims to test whether in the regression model, all research instruments are either bound variables, free variables or both have normal distributions or not.

b. Multicolinearity Test

Multicolinearity test is a test that aims to test the regression model found a correlation between free variables. The regression model is said to be good if there is no correlation between the independent variables. 
c. Heteroskedastisitas Test

Heteroskedastisity test is a test that aims to test whether in the regression model there is a variant inequality from one observation to another.

4. Multiple Lineer Regression Test

Multiple linear regression analysis is a tool of value forecasting analysis of the influence of two or more free variables on bound variables, to prove whether or not there is a function relationship or causal relationship between two or more free variables with one bound variable. (Hartanto et al., 2018).

5. Hipotesisis Test

a. T Test

$\mathrm{T}$ test is a test that aims to find out how far a partially independent variable affects dependent variables. (Marjaya \&Pasaribu, 2019)

b. F Test

$F$ Test is a test that aims to determine whether or not there is a mutual influence of free variables on bound variables conducted test F. (Hartanto et al., 2018) Koefisien

c. Determinant $(\mathrm{R})$

The coefficient of determination (R2) is one of the statistical values that can be used to determine how much influence between variable $\mathrm{X}$ and variable $\mathrm{Y}$. (Syafrina, 2017)

d. Paired Sample T Test

Paired Sample T Test is a test used to compare the difference between two means of two paired samples assuming normally distributed data. The paired samples came from the same subject, each variable taken in different situations and circumstances. (Welley et al., 2020)

\section{RESULTS AND DISCUSSION}

\section{Respondent Description}

The results of this study the authors have conducted a test of questionnaire data obtained. From the questionnaire obtained by 37 respondents from several MSMEs that have been mentioned in the population. Data testing includes various tests, this is so that the author does not get wrong about the actual circumstances. In order for the test results to be accurate, the author in conducting the test using SPSS 25. For the methods and types of testing conducted in this study are as follows.

\section{Data Analysis Result}

1. Validity Test Result

Validity tests are used to determine if any questions or statements on the questionnaire should be omitted or replaced because they are considered irrelevant. Validity is the degree of accuracy between data that occurs in research objects and data that can be reported by researchers. Validity tests are often used to measure the determination of an item in a questionnaire. (Ahyar et al., 2020) 
Tabel 1. Validity Test Result

\begin{tabular}{|c|c|c|c|c|}
\hline Variable & Questions/Indicators & $\begin{array}{l}\text { Pearson } \\
\text { Correlation } \\
\text { (R Hitung) }\end{array}$ & $\begin{array}{c}\text { Standard } \\
\text { Validity (R } \\
\text { Table) }\end{array}$ & Description \\
\hline \multirow{10}{*}{$\begin{array}{l}\text { Work Motivation } \\
\text { (X1) }\end{array}$} & $X 1.1$ & 0.404 & 0.325 & Valid \\
\hline & $X 1.2$ & 0.524 & 0.325 & Valid \\
\hline & X1.3 & 0.667 & 0.325 & Valid \\
\hline & $\times 1.4$ & 0.680 & 0.325 & Valid \\
\hline & $\times 1.5$ & 0.666 & 0.325 & Valid \\
\hline & X1.6 & 0.716 & 0.325 & Valid \\
\hline & $\mathrm{X} 1.7$ & 0.753 & 0.325 & Valid \\
\hline & X1.8 & 0.772 & 0.325 & Valid \\
\hline & X1.9 & 0.685 & 0.325 & Valid \\
\hline & $X 1.10$ & 0.625 & 0.325 & Valid \\
\hline \multirow{10}{*}{$\begin{array}{l}\text { Work Condition } \\
\text { (X2) }\end{array}$} & $\times 2.1$ & 0.412 & 0.325 & Valid \\
\hline & $\times 2.2$ & 0.723 & 0.325 & Valid \\
\hline & $X 2.3$ & 0.403 & 0.325 & Valid \\
\hline & $\times 2.4$ & 0.632 & 0.325 & Valid \\
\hline & $\times 2.5$ & 0.410 & 0.325 & Valid \\
\hline & $X 2.6$ & 0.416 & 0.325 & Valid \\
\hline & $\times 2.7$ & 0.399 & 0.325 & Valid \\
\hline & $X 2.8$ & 0.673 & 0.325 & Valid \\
\hline & $\times 2.9$ & 0.503 & 0.325 & Valid \\
\hline & $\times 2.10$ & 0.554 & 0.325 & Valid \\
\hline \multirow{10}{*}{$\begin{array}{c}\text { Employee } \\
\text { Performance } \\
\text { (Y) }\end{array}$} & Y.1 & 0.800 & 0.325 & Valid \\
\hline & Y.2 & 0.793 & 0.325 & Valid \\
\hline & Y.3 & 0.755 & 0.325 & Valid \\
\hline & Y.4 & 0.608 & 0.325 & Valid \\
\hline & Y.5 & 0.822 & 0.325 & Valid \\
\hline & Y.6 & 0.809 & 0.325 & Valid \\
\hline & Y.7 & 0.516 & 0.325 & Valid \\
\hline & Y.8 & 0.591 & 0.325 & Valid \\
\hline & Y.9 & 0.593 & 0.325 & Valid \\
\hline & Y.10 & 0.647 & 0.325 & Valid \\
\hline
\end{tabular}

Source : The results of processing the author using IBM SPSS 25

From the observations on the $r$ Tabel of 37 samples obtained by 0.325 . Based on the results of the validity test conducted, it is generated that all variable instruments from per question all have a calculated value of $>$ rTabel of 0.325 . Therefore it can be concluded that all items are valid.

2. Reliability Test Results

Reliability Test is a test used to know the extent to which measurement results remain consistent when measured twice or more against the same symptoms using the same 
gauge. Reliability testing is conducted using the SPSS program. Criteria of a research instrument are said to be reliable, if the reliability coefficient $(r)>0.6$ (Astarina, 2018).

Tabel 2. Reliability Test

\begin{tabular}{cccccc}
\hline \multicolumn{2}{l}{ Work Motivation (X1) } & \multicolumn{2}{c}{ Work Condition (X2) } & \multicolumn{2}{c}{ Employee Performance (Y) } \\
\hline \multicolumn{2}{l}{ Reliability Statistics } & \multicolumn{2}{c}{ Reliability Statistics } & \multicolumn{2}{c}{ Reliability Statistics } \\
\hline Cronbach's & $\mathrm{N}$ of & Cronbach's & $\mathrm{N}$ of & Cronbach's & N of Items \\
Alpha & Items & Alpha & Items & Alpha & 10 \\
.835 & 10 & .670 & 10 & .879 & \\
\hline
\end{tabular}

Source : Author processing results using IBM SPSS 25

From the results of reliability tests conducted showed that the three variable instruments were declared reliable because it has Croanbach Alpha $>0.60$

3. Classic Assumption Test

a. Normality Data Test

Test is conducted before regression and collation analysis that aims to test whether a variable regression is bound to a free variable or both have a normal distribution or not. A good regression model is normal data distribution and regression also meets the normality of regression or near normality. With SPSS test this test can be done using Normal Probabily Plot (NPP) method.(Hartanto et al., 2018)

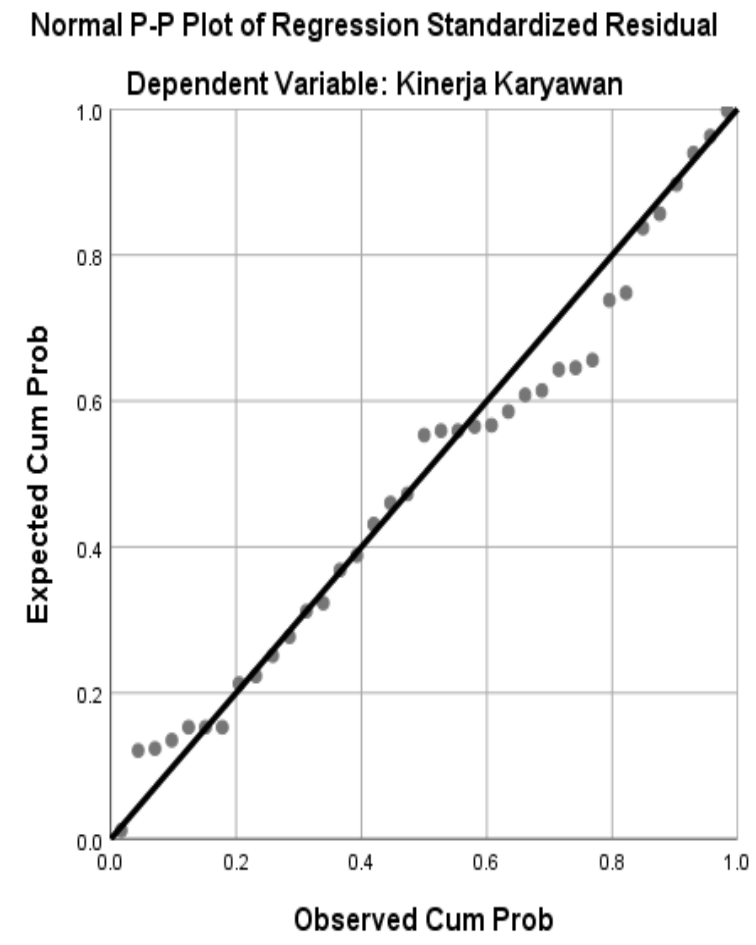

Picture 2. Grafik Normalitas

Source : Author processing results using IBM SPSS 25

Based on the P-Plot image above, dplot data (dots) spread between diagonal line lines, meaning that the regression model meets normality assumptions and is feasible to predict bound variables (employee performance). In addition to using the Normal Probabily Plot (NPP) method can also be seen by analysis of the Columnograph-Smirnov method. Standardized residual values are normally distributed if sig $>$ from 0.05 . 
Tabel 3. One-Sample Kolmogorov-Smirnov Test

\begin{tabular}{llr}
\hline \multirow{2}{*}{ Normal Parameters ${ }^{\mathrm{a}, \mathrm{b}}$} & \multicolumn{2}{c}{$\begin{array}{c}\text { Unstandardized } \\
\text { Residual }\end{array}$} \\
\cline { 2 - 3 } & Mean & 37 \\
\cline { 2 - 3 } & Std. Deviation & .0000000 \\
\cline { 2 - 3 } & Absolute & .124 \\
\cline { 2 - 3 } & Positive & .124 \\
\cline { 2 - 3 } & Negative & -.087 \\
\hline Test Statistic & .124 \\
\hline Asymp. Sig. (2-tailed) & $.166^{\mathrm{c}}$ \\
\hline a. Test distribution is Normal. & \\
\hline b. Calculated from data. & \\
\hline c. Lilliefors Significance Correction. & \\
\hline Source : Author processing results using IBM SPSS 25 & \\
\hline
\end{tabular}

Based on the table above seen the value of Asymp. Sig of $0.166>0.05$ so it can be concluded that the data is normally distributed.

Below is a test of normality with a histogram chart as follows.

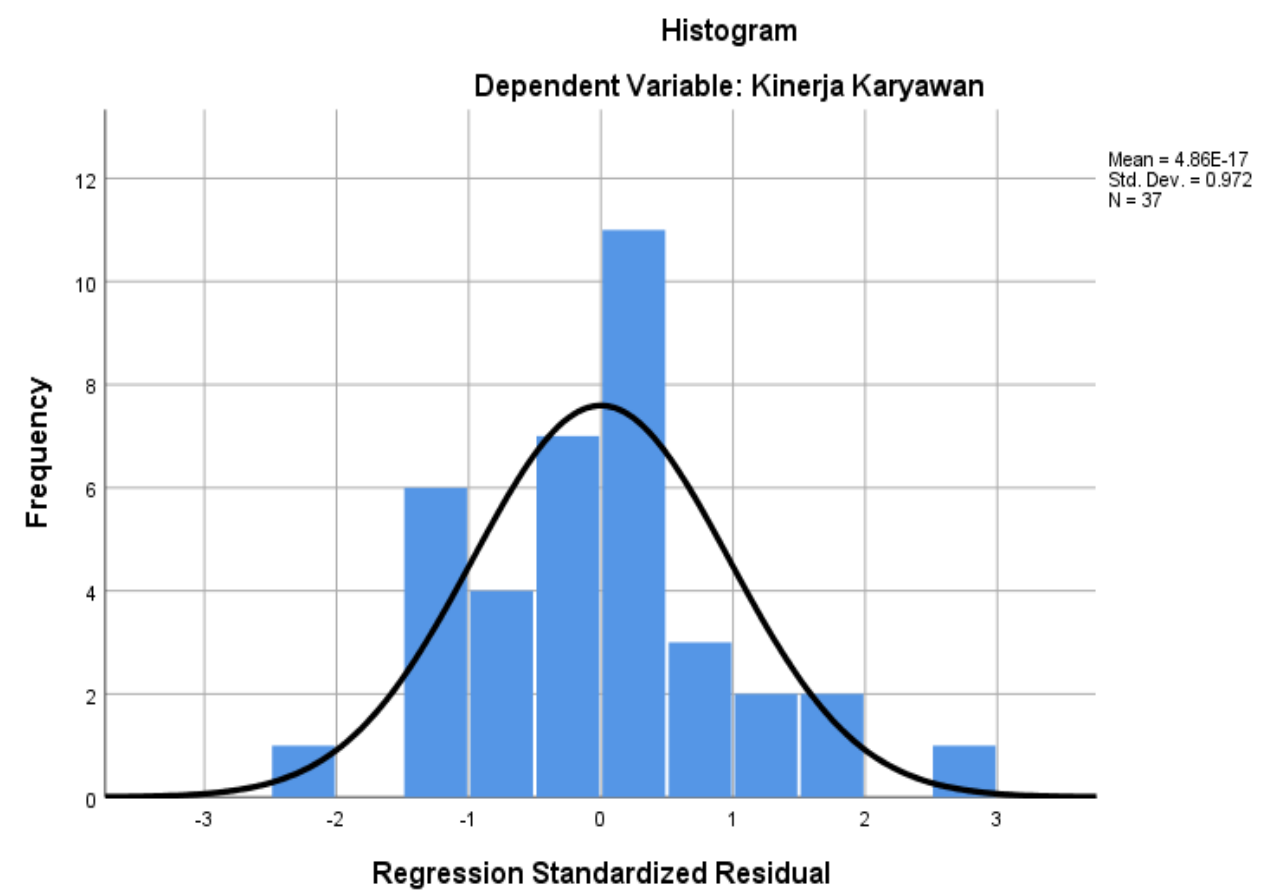

Picture 3. Grafik Histogram Normalitas

Source : Author processing results using IBM SPSS 25

In the picture above it appears that the dots form a bell curve and the value of Sandar Dev $=0.972>0.80$, so that the regression model can meet the element of normality.

b. Multikolinieritas Test

The test method used is to look at tolerance inflation factor between free variables. If the correlation coefiesien value between each free ariabel is less than or $<10$ and 
tolerance value above $>0.1$ then there is no multicolonierity. The test results are as follows:

Tabel 4. Multicolerity Assumption Test Results

\begin{tabular}{|c|c|c|c|c|c|c|c|}
\hline \multicolumn{8}{|c|}{ Coefficients $^{a}$} \\
\hline \multirow[b]{2}{*}{ Model } & \multicolumn{2}{|c|}{$\begin{array}{c}\text { Unstandardized } \\
\text { Coefficients }\end{array}$} & \multirow{2}{*}{$\begin{array}{c}\text { Standardized } \\
\text { Coefficients } \\
\text { Beta }\end{array}$} & \multirow[b]{2}{*}{$\mathrm{T}$} & \multirow[b]{2}{*}{ Sig. } & \multicolumn{2}{|c|}{$\begin{array}{c}\text { Collinearity } \\
\text { Statistics }\end{array}$} \\
\hline & 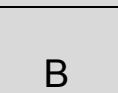 & $\begin{array}{l}\text { Std. } \\
\text { Error }\end{array}$ & & & & $\begin{array}{c}\text { Toleranc } \\
\mathrm{e}\end{array}$ & VIF \\
\hline (Constant) & 9.631 & 6.598 & & 1.460 & .154 & & \\
\hline $\begin{array}{l}\text { Motivasi } \\
\text { Kerja }\end{array}$ & .221 & .150 & .236 & 1.475 & .149 & .653 & 1.530 \\
\hline Kondisi Kerj & .570 & .186 & .490 & 3.062 & .004 & .653 & 1.530 \\
\hline
\end{tabular}

a. Dependent Variable: Kinerja Karyawan

Source : Author processing results using IBM SPSS 25

Based on table 4 it is known that the VIF value of the working motivation variable (X1) and the working condition variable (X2) is 1,530 and the Tolerance Value value is $0.653>0.1$ then the data does not occur multicolonierity.

c. Heteroskedastisitas Test

The way to see the heteroskedastisitas in the regression equation is to look at the dots on the Scar Plot. If the point forms a certain pattern then regression is indicated by heteroskedastisitas. (Salutondok \&Soegoto2, 2015).

The results of the heteroskedastisitas test are shown below.

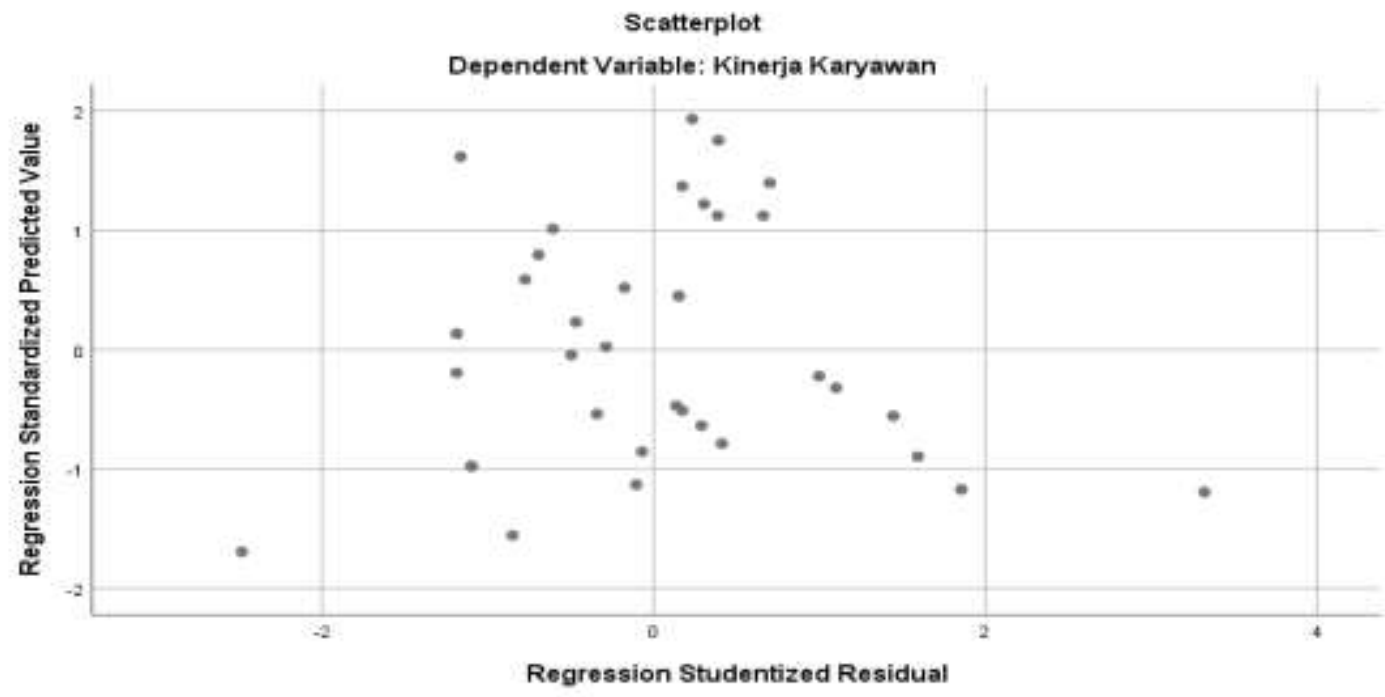

Picture 4. Heterosdastisitas Test Result

Source : Author processing results using IBM SPSS 25

Based on the tests conducted showed no symptoms of heteroskedastisitas because the dots spread randomly and did not show a specific pattern.

4. $\quad$ Multiple Linear Regression Analysis

In this study used multiple linear regression analysis. This analysis is an analysis conducted with the aim of measuring the strength of two or more variables and also 
shows the direction of the relationship between dependent variables and independent variables. (Marjaya \&Pasaribu, 2019).

From this study obtained the following data.

Tabel 5. Hasil Analisis Regresi Linier Berganda

Coefficients $^{\mathrm{a}}$

\begin{tabular}{|c|c|c|c|c|c|}
\hline \multirow[b]{2}{*}{ Model } & \multicolumn{2}{|c|}{$\begin{array}{c}\text { Unstandardized } \\
\text { Coefficients }\end{array}$} & \multirow{2}{*}{$\begin{array}{c}\begin{array}{c}\text { Standardized } \\
\text { Coefficients }\end{array} \\
\text { Beta } \\
\end{array}$} & \multirow[b]{2}{*}{$\mathrm{T}$} & \multirow[b]{2}{*}{ Sig. } \\
\hline & B & Std. Error & & & \\
\hline (Constant & 9.631 & 6.598 & & 1.460 & .154 \\
\hline $\mathrm{X} 1$ & .221 & .150 & .236 & 1.475 & .149 \\
\hline $\bar{X} 2$ & .570 & .186 & .490 & 3.062 & .004 \\
\hline
\end{tabular}

a. Dependent Variable: $Y$

Source : Author processing results using IBM SPSS 25

From the data above, it can be known that the value of the work motivation coefficient is worth 0.236 meaning that if the motivation variable increases, it will be followed by an improvement in employee performance. Then the coefficient value of working conditions worth 0.490 means that if the variable working conditions occur an increase, it will be followed by an improvement in employee performance.

5. Hipotesis Test

a. T Test

This T-test is a test that aims to find out how far partially independent variables affect dependent variables.

Tabel 6. T Test Analysis Results Coefficients $^{\mathrm{a}}$

\begin{tabular}{lccccc}
\hline & \multicolumn{2}{c}{$\begin{array}{c}\text { Unstandardized } \\
\text { Coefficients }\end{array}$} & $\begin{array}{c}\text { Standardized } \\
\text { Coefficients }\end{array}$ & & \\
\cline { 2 - 5 } Model & $\mathrm{B}$ & Std. Error & Beta & $\mathrm{t}$ & Sig. \\
\hline (Constant) & 9.631 & 6.598 & & 1.460 & .154 \\
\hline $\mathrm{X} 1$ & .221 & .150 & .236 & 1.475 & .149 \\
\hline $\mathrm{X} 2$ & .570 & .186 & .490 & 3.062 & .004 \\
\hline
\end{tabular}

a. Dependent Variable: $Y$

Source : Author processing results using IBM SPSS 25

Based on the table above about the test results $t$ shows that the Variable Work Motivation (X1) has a signification value of 0.154 which means greater than the value of 0.05 . Then it can be concluded that the Variable Work Motivation (X1) has no significant effect on Employee Performance Variable (Y). While the Working Condition Variable (X2) has a significant value of 0.004 which means $<0.05$ then it can be said that the Variable Working Condition (X2) has a significant effect on the variable Knerja Karyawan (Y).

b. F Test

Test $\mathrm{F}$ is used to determine whether or not there is an influence simultaneously or together free variables against bound variables conducted test $F$. If the value of $F$ count is greater than F table, then it is stated that there is at least one free variable 
that contributes to predicting the value of the independent variable or vice versa. (Hartanto et al., 2018)

Tabel 7. F Test Result

\begin{tabular}{|c|c|c|c|c|c|}
\hline \multicolumn{6}{|c|}{ ANOVA $^{\mathrm{a}}$} \\
\hline Model & Sum of Squares & df & $\begin{array}{l}\text { Mean } \\
\text { Square }\end{array}$ & $\mathrm{F}$ & Sia. \\
\hline Regression & 369.427 & 2 & 184.713 & 12.907 & $.001^{\mathrm{b}}$ \\
\hline Residual & 486.573 & 34 & 14.311 & & \\
\hline Total & 856.000 & 36 & & & \\
\hline \multicolumn{6}{|c|}{ a. Dependent Variable: $\mathrm{Y}$} \\
\hline b. Predictors & istant), X2, X1 & & & & \\
\hline
\end{tabular}

source : Author processing results using IBM SPSS 25

Based on the data obtained from the simultaneous $\mathrm{F}$ test above known significance value for the simultaneous influence of $\mathrm{X} 1$ and $\mathrm{X} 2$ on $\mathrm{Y}$ is $0.001<0.05$ so that it can be concluded simultaneously there is an influence of work motivation (X1) and working conditions $(\mathrm{X} 2)$ on employee performance $(\mathrm{Y})$.

c. Coefficient of Determination

The coefficient of determination (R2) is one of the statistical values that can be used to determine how much influence between variable $X$ and variable $Y$. (Syafrina, 2017). In this study obtained the following data.

Tabel 8. Coefficient of Determination

\begin{tabular}{llrrrr}
\hline & \multicolumn{4}{c}{ Model Summary } \\
\hline Model & $\mathrm{R}$ & $\mathrm{R}$ Square & $\begin{array}{c}\text { Adjusted } \mathrm{R} \\
\text { Square }\end{array}$ & Std. Error of the Estimate \\
\hline 1 & $.657^{\mathrm{a}}$ & .432 & \multicolumn{2}{c}{.398} & 3.783 \\
\hline
\end{tabular}

a. Predictors: (Constant), X2, X1

Source : Author processing results using IBM SPSS 25

From the data above obtained the value of coefficient of determination(R2) is 0.432 . This shows the percentage of influence of motivation variables and working conditions on employee performance by $43.2 \%$ and the remaining $56.8 \%$ influenced by other factors.

d. $\quad$ Paired Sample T Test

Paired Sample T Test is a test used to compare the difference between two means of two paired samples assuming normally distributed data. Paired samples come from the same subject, each variable taken in different situations and circumstances. For correlation comparison can be indicated by a table of test data results as follows.

Tabel 9. Paired Sample Correlation

\begin{tabular}{llccc}
\hline \multicolumn{4}{c}{ Paired Samples Correlations } \\
\hline & N & Correlation & Sig. \\
\hline Pair 1 & $\begin{array}{l}\text { X1_Sebelum_Covid \& } \\
\text { X1_Saat_Covid }\end{array}$ & .552 & .000 \\
\hline Pair 2 & $\begin{array}{l}\text { X2_Sebelum_Covid \& } \\
\text { X2_Saat_Covid }\end{array}$ & 37 & -.001 & .997 \\
\hline Pair 3 & Y_Sebelum_Covid \& Y_Saat_Covid & 37 & .495 & .002 \\
\hline
\end{tabular}

Source : Author processing results using IBM SPSS 25 
From the results of the table above known correlation value at X1 of 0.552 with a significant value of 0.000 so that it can be said that there is a relationship between the variable work motion (X1) before and work motivation (X1) during covid. Then the correlation value in $\mathrm{X} 2$ is -.001 with a significant value of 0.997 so it can be said that there is no correlation between (X2) before covid and (X2) during covid. Meanwhile, the correlation $Y$ value of 0.495 with a significant value of 0.002 so that it can be said that the performance of employees before covid has correlation with the performance of employees during covid.

To find out the comparison results of paired sample test from this study can be seen in the table as follows.

Tabel 10. Paired sample Test Analysis Result

\begin{tabular}{|c|c|c|c|c|c|c|c|c|c|}
\hline & \multicolumn{5}{|c|}{ Paired Differences } & \multirow[b]{3}{*}{$\mathrm{t}$} & \multirow[b]{3}{*}{ Df } & \multirow{3}{*}{$\begin{array}{l}\text { Sig. } \\
(2- \\
\text { tailed } \\
\quad)\end{array}$} \\
\hline & & \multirow[b]{2}{*}{ Mean } & \multirow{2}{*}{$\begin{array}{l}\text { Std. } \\
\text { Devia } \\
\text { tion }\end{array}$} & \multirow{2}{*}{$\begin{array}{l}\text { Std. } \\
\text { Error } \\
\text { Mean }\end{array}$} & \multicolumn{2}{|c|}{$\begin{array}{c}95 \% \\
\text { Confidence } \\
\text { Interval of the } \\
\text { Difference }\end{array}$} & & & \\
\hline & & & & & $\begin{array}{l}\text { Low } \\
\text { er }\end{array}$ & Upper & & & \\
\hline Pair 1 & $\begin{array}{l}\text { X1_Sblm } \\
\text { Covid - } \\
\bar{X} 1 \text { Saat } \\
\overline{\text { Covid }}\end{array}$ & 1.054 & 2.838 & .467 & .108 & 2.000 & 2.259 & 36 & .030 \\
\hline Pair 2 & $\begin{array}{l}\text { X2_Sblm } \\
\text { Covid - } \\
\text { X2_Saat } \\
\text { Covid }\end{array}$ & 1.703 & 4.189 & .689 & .306 & 3.099 & 2.472 & 36 & .018 \\
\hline Pair 3 & $\begin{array}{l}\text { Y_Sblm_ } \\
\text { Covid - } \\
\text { Y_Saat_ } \\
\text { Covid }\end{array}$ & .459 & 2.834 & .466 & -.486 & 1.404 & .986 & 36 & .331 \\
\hline
\end{tabular}

Source : Author processing results using IBM SPSS 25

From the above data shows that working motivation variable (X1) has a sig value. (2-tailed) of $0.030<0.05$ then there is a significant difference between the motivation of work before and during covid. Therefore the $\mathrm{H} 4$ statement is accepted. Then in the variable working conditions (X2) has a sig value. (2-tailed) of $0.018<0.05$ then it can be concluded that there is a significant difference between working conditions before and during covid. Therefore, the $\mathrm{H} 5$ statement is accepted. And in the employee performance variable $(Y)$ has a sig. (2-tailed) value of $0.331>0.05$ then it can be said that there is no significant difference between the performance of employees in the period before and during Covid-19, then $\mathrm{H} 6$ is rejected. 


\section{E. CONCLUSION}

The $t$ test result shows that the Work Motivation variable $(\mathrm{X} 1)$ has a signification value of 0.154 which means greater than 0.05 . So it can be concluded that the Variable Work Motivation (X1) has no significant effect on employee performance variables $(\mathrm{Y})$, then $\mathrm{H} 1$ is rejected. Variable Working Conditions $(\mathrm{X} 2)$ has a significant value of 0.004 which means $<0.05$ then it can be concluded that the Variable Working Condition (X2) has a significant effect on the variable Employee Performance $(\mathrm{Y})$, then $\mathrm{H} 2$ is accepted.

Based on simultaneous $F$ testing known significance value for the simultaneous influence of $\mathrm{X} 1$ and $\mathrm{X} 2$ on $\mathrm{Y}$ is $0.001<0.05$ so that it can be concluded simultaneously there is an influence of work motivation (X1) and working conditions (X2) on employee performance $(\mathrm{Y})$, then $\mathrm{H} 3$ is accepted.

In the comparison test the working motivation variable $(\mathrm{x} 1)$ has a sig value. (2-tailed) of $0.030<0.05$, there is a significant difference between work motivation before and during covid-19. Therefore the $\mathrm{H} 4$ statement is received.

In the test comparison variable working condition(X2) has a sig value. (2-tailed) of 0.018 which means $<0.05$ then it can be concluded there is a significant difference between working conditions before and during covid-19. Therefore, the H5 statement is accepted.

In the comparison test on the employee performance variable $(y)$ has a sig value. (2tailed) amounting to 0.331 which means $>0.05$, it can be concluded that there is no significant difference between the performance of employees in the period before and during covid-19, so $\mathrm{H} 6$ is rejected.

\section{REFERENCE}

Agung, I. M. (2020). Memahami Pandemi Covid-19 Dalam Perspektif Psikologi Sosial. Psikobuletin:Buletin IImiah Psikologi, 1(2), 68-84.

Ahyar, H., Maret, U. S., Andriani, H., Sukmana, D. J., Mada, U. G., Hardani, S.Pd., M. S., Nur Hikmatul Auliya, G. C. B., Helmina Andriani, M. S., Fardani, R. A., Ustiawaty, J., Utami, E. F., Sukmana, D. J., \& Istiqomah, R. R. (2020). Buku Metode Penelitian Kualitatif \& Kuantitatif (A. Husnu Abadi, A.Md. (ed.); Issue March). Pustaka IImu Grup.

Alfiah, S., Andriani, J., Lesmana, R., Sunardi, N., \& Furyanah, A. (2019). Manajemen Pengelolaan Desa Wisata Pada Desa Cimanggu, Kecamatan Cisalak, Kabupaten Subang, Privinsi Jawa Barat (Studi Kasus pada Curug Paok dan Bukit Pasir Jaka). Jurnal Abdi Masyarakat Humanis, 1(1).

Amri, A. (2020). Dampak Covid-19 Terhadap UMKM di Indonesia. Jurnal Brand, 2(1), 147-153.

Astarina, I. (2018). Pengaruh Motivasi Dan Kompensasi Terhadap Kinerja Karyawan Pada Pt. Alfa Scorpii Pematang Reba. Jurnal Manajemen Dan Bisnis, 7(4), 1-9. https://doi.org/10.34006/jmb.v7i4.2

Bahtiar, R. R., \& Saragih, J. P. (2020). Dampak Covid-19 Terhadap Perlambatan Ekonomi Sektor UMKM. Jurnal Bidang Ekonomi Dan Kebijakan Publik, 12(6), 19-24.

Bawono, M. O., Asih, W., \& Kurnia Astianti. (2019). Gaya Kepemimpinan, Motivasi Kerja, Disiplin Kerja Dan Kinerja: Studi Kasus Terhadap Pegawai Tidak Tetap Smp Negeri 4 Pakem. 9(2), 300-315. 


\section{ISSN (print) : 2598-9545 \& ISSN (online) : 2599-171X

Hartanto, Hendriani, S., \& Maulida, Y. (2018). Analisis pengaruh kondisi kerja, motivasi kerja, dan disiplin kerja terhadap kinerja pegawai kantor wilayah direktorat jenderal kekayaan Negara Riau, Sumatera Barat, dan Kepulauan Riau. Tepak Manajemen Bisnis, X(2), 226-241.

Isvandiari, A., \& Fuadah, L. (2017). Pengaruh Kompensasi dan Disiplin Kerja Terhadap Kinerja Karyawan Bagian Produksi PG. Meritjan Kediri. Jurnal IImiah Bisnis Dan Ekonomi Asia, 11(2), 1-8. https://doi.org/10.32812/jibeka.v11i2.54

Lawasi, E. S., \& Triatmanto, B. (2017). Pengaruh Komunikasi, Motivasi Dan Kerjasama Tim Terhadap Peningkatan Kinerja Karyawan. Jurnal Manajemen \& Kewirausahaan, 5(1), 2374-2376.

Lesmana, R., Sutarman, A., \& Sunardi, N. Building A Customer Loyalty Through Service Quality Mediated by Customer Satisfaction. American Journal of Humanities and Social Sciences Research (AJHSSR), 5(3), 38-45

Lesmana, R., Sunardi, N., \& Kartono. The Effect of Financing and Online Marketing on MSMEs Income Increasing at Intermoda Modern Market BSD City Tangerang Selatan. American Journal of Humanities and Social Sciences Research (AJHSSR), 5(7), 25-34

Marjaya, I., \& Pasaribu, F. (2019). Pengaruh Kepemimpinan, Motivasi, Dan Pelatihan Terhadap Kinerja Pegawai. Maneggio: Jurnal IImiah Magister Manajemen, 2(1), 129 147. https://doi.org/10.30596/maneggio.v2i1.3650

Maulana, F. (2015). Pengaruh Motivasi Intrinsik, Motivasi Ekstrinsik Dan Komitmen Organsasi Terhadap Kinerja Karyawan Pada Bank Btn Kantor Cabang Malang. Jurnal Administrasi Bisnis S1 Universitas Brawijaya, 22(1), 85893.

Nawastuti, R. (2018). Studi Kasus pada PT. Bank Tabungan Negara Tbk. Kantor CabanNawastuti, Rati Ekonomig Syariah Semarang).

Salutondok, Y., \& Soegoto2, A. S. (2015). Pengaruh Kepemimpinan, Motivasi, Kondisi Kerja Dan Disiplin Terhadap Kinerja Pegawai Di Kantor Sekretariat Dprd Kota Sorong. Jurnal EMBA 849 Vol.3 No.3 Sept. 2015, Hal.849-862, 3(3), 31-36. https://doi.org/10.5848/ilo.978-9-221279-05-1_5

Setywan, E. B. (2020). Pengaruh Disiplin Kerja Dan Motivasi Terhadap Karakteristik Pekerjaan (Study Kasus Di Politeknik Api Yogyakarta). 10(1), 70-78.

Sugiyono. (2013). Metode Penelitian Kuantitatif, Kualitatif dan R\&D. Alfabeta.

Sugiyono. (2015). Metode Penelitian Pendidikan (Pendekatan Kuantitatif, Kualitatif dan $R \& D)$. Alfabeta.

Sunardi, N., \& Lesmana, R. (2020). Konsep Icepower (Wiramadu) sebagai Solusi Wirausaha menuju Desa Sejahtra Mandiri (DMS) pada Masa Pandemi Covid19. JIMF (Jurnal IImiah Manajemen Forkamma), 4(1).

Surjosuseno, D. (2015). Pengaruh Lingkungan Kerja Dan Motivasi Kerja Terhadap Kinerja Karyawan Pada Bagian Produksi Ud Pabrik Ada Plastic. Agora, 3(2), 175-179.

Syafrina, N. (2017). Pengaruh Disiplin Kerja Terhadap Kinerja Karyawan Pada PT. Suka Fajar Pekan Baru. Eko Dan Bisnis, 4(8), 1-12.

Welley, M. M., Oroh, F. N. S., \& Walangitan, M. D. B. (2020). Perbandingan harga saham perusahaan farmasi BUMN sbelum dan sesudah Pengembangan Vaksin Virus Corona (COVID-19). Jmbi Unsrat, 7(3), 571-579. 